\title{
Pakistan's Energy Sector Issues: Energy Efficiency and Energy Environmental Links
}

\section{Tariq Husain*}

\begin{abstract}
This paper analyzes Pakistan's energy sector issues and highlights (i) the importance of the link between energy and the environment, and (ii) the central importance of energy efficiency for high return demand-side solutions to meet the country's energy needs. The paper argues that energy planning should integrate the external cost of energy use in deciding about the composition of supply: coal, oil, gas, hydropower, renewable, nuclear, and solar. By utilizing external cost estimates made by the European Commission for Europe, and the US National Academy of Sciences, a total cost (external + internal) ranking of primary energy sources for Pakistan is estimated. This estimate is at the low end of the cost spectrum because classic pollutants-sulfur dioxide, nitrogen oxides, carbon monoxide-in Pakistan are significantly higher than in Europe or the US. The paper also discusses the experiences of China and OECD countries in increasing energy-wide efficiency. A central lesson emerging from the analysis is that Pakistan will have to significantly increase its energy-related research and development expenditure in order to adequately address its energy sector issues. A quadrupling from $0.25 \%$ of gross domestic product is recommended over a decade.
\end{abstract}

Keywords: Energy, policy, environment, Pakistan.

JEL Classification: Q48, Q47, Q5.

\section{Introduction}

Energy is the life blood of socioeconomic development. It is essential for technological applications that promote productivity increases. The three domains where energy is used are the production of electricity, the extraction/generation of thermal energy (heating and cooling), and transportation. During the past two centuries, fossil fuels (coal, oil, and gas) have been the main sources used to meet humanity's energy

\footnotetext{
${ }^{*}$ Former Director, World Bank.
} 
requirements. Currently, fossil fuel sustains about 80 percent of global energy needs. But these resources, formed by nature over millions of years, are finite. Large fossil fuel reserves are also unevenly distributed among countries. They are concentrated in a small number of countries with about half the low- and middle-income countries having no or very few oil and gas reserves. Even rich countries are not well endowed with oil and gas, although coal is more widely distributed.

Energy uses and national income per capita are positively correlated. Table-1 gives energy consumption per capita per year for selected countries. Pakistan consumes 490 kilograms of oil equivalent ${ }^{1}$ (kgoe), China 1,320 and the US, about 7,900. Although the availability of fossil fuel has enabled wealth creation by modern civilization, today we are faced with two major challenges in the utilization of energy. The first is to find adequate substitutes for the declining resources of fossil fuel. The second relates to the link between energy and the environment. The link is evident in all phases of energy production, conversion, and use. In Pakistan, the most serious energy-environment problems are the effects of the emission of particulate matter (TSP, $\mathrm{PM}_{10}$ ), indoor pollution from the use of biomass fuels, sulfur dioxide $\left(\mathrm{SO}_{2}\right)$, nitrogen oxide $(\mathrm{NOx})$, carbon monoxide (CO) and heavy metals (lead, mercury) generated by the use of fossil fuel for transportation and generation of electricity (see Table-2). While at the global leve1, Pakistan is not a significant contributor to the production of carbon dioxide $\left(\mathrm{CO}_{2}\right)$ (producing 0.9 tons/capita), as we look ahead Pakistan could (like China at $4.6 \mathrm{~T} \mathrm{CO}_{2} /$ capita) become a significant contributor to climate change. The US generates $19 \mathrm{~T} \mathrm{CO}_{2} /$ capita and Canada 16.7, but France, due to its use of nuclear energy, generates only $6.2 \mathrm{~T} \mathrm{CO}_{2} /$ capita.

\footnotetext{
${ }^{1}$ Ton of oil equivalent (TOE) is a widely employed unit of energy and corresponds to 10 giga-calories or $4.1868 * 10^{10}$ joules; kgoe is $10^{-3}$ TOE.
} 
Table-1: Energy Consumption per Capita

\begin{tabular}{lc}
\hline Country & Energy Consumption per Capita (2007) (kgoe) \\
\hline Pakistan & 490 \\
India & 490 \\
China & 1,320 \\
Thailand & 1,560 \\
Malaysia & 2,420 \\
UK & 3,895 \\
USA & 7,885 \\
Low-Income Countries & 490 \\
Middle-Income Countries & 1,510 \\
High-Income Countries & 5,520 \\
\hline
\end{tabular}

Source: International Energy Information Agency (IAEA). 
Table-2: External Cost Variable for Energy and Transport

\begin{tabular}{|c|c|c|}
\hline Impact Category & Pollutant/Burden & Effects \\
\hline $\begin{array}{l}\text { Human Health: } \\
\text { Mortality }\end{array}$ & $\mathrm{PM}_{10}{ }^{\mathrm{a}}, \mathrm{SO}_{2}, \mathrm{NO}_{\mathrm{x},} \mathrm{O}_{3}$ & Reduction in life expectancy \\
\hline $\begin{array}{l}\text { Human Health: } \\
\text { Morbidity }\end{array}$ & $\begin{array}{l}\mathrm{PM}_{10}, \mathrm{O}_{3}, \mathrm{SO}_{2,} \\
\mathrm{PM}_{10}, \mathrm{O}_{3} \\
\mathrm{PM}_{10}, \mathrm{CO} \\
\mathrm{PM}_{10}\end{array}$ & $\begin{array}{l}\text { Respiratory hospital admissions } \\
\text { Restricted activity days } \\
\text { Congestive heart failure } \\
\text { Cerebro-vascular hospital } \\
\text { admissions } \\
\text { Cases of chronic cough in } \\
\text { children } \\
\text { Cough in asthmatics } \\
\text { Lower respiratory symptoms } \\
\text { Asthma attacks }\end{array}$ \\
\hline Crops & $\begin{array}{l}\mathrm{NO}_{\mathbf{x}} \mathrm{SO}_{2} \\
\mathrm{O}_{3}\end{array}$ & $\begin{array}{l}\text { Yield change for wheat, barley, } \\
\text { rye, oats, potatoes, sugar, beets } \\
\text { Yield change for wheat, barley, } \\
\text { rye, oats, potatoes, rice, } \\
\text { tobacco, sunflower seed } \\
\text { Increased need for liming }\end{array}$ \\
\hline Global Warming & $\mathrm{CO}_{2}, \mathrm{CH}_{4}, \mathrm{~N}_{2} \mathrm{O}, \mathrm{N}, \mathrm{S}$ & $\begin{array}{l}\text { Worldwide effects on mortality, } \\
\text { morbidity, coastal impacts, } \\
\text { agriculture, energy demand, and } \\
\text { economic impacts due to } \\
\text { temperature change and sea } \\
\text { level rise }\end{array}$ \\
\hline Ecosystems & $\begin{array}{l}\text { Acid deposition, } \\
\text { nitrogen deposition }\end{array}$ & $\begin{array}{l}\text { Acidity and eutrophication } \\
\text { (avoidance cost for reducing } \\
\text { areas where critical loads are } \\
\text { exceeded) }\end{array}$ \\
\hline
\end{tabular}

The above is a subset of the damages covered by the source study.

a Particulate matter with a diameter of less than 10 microns (one micron equals one millionth of a meter) including secondary particles (sulfate and nitrate aerosols)

Source: External Costs: Research Results on Socio-Environmental Damage due to Electricity and Transport: European Commission Study (2003). 


\section{Energy Efficiency and the Energy-Environment Link}

Energy efficiency is a measurable quantity. It is the ratio of energy input into a process to energy or work (electricity, heat, transportation) produced by that process. Conservation in use by the final consumer is an integral part of the energy efficiency of an economy. Improving conversion efficiency in the production of electricity, heat, or movement (transportation) is the second component. A widely used economy-wide measure of energy efficiency is kilogram of oil equivalent (kgoe) per $\$ 1,000$ GDP. The UNDP Millennium Data Center publishes this measure for most UN members. For Pakistan, the measure in 2006 was 219 kgoe per $\$ 1,000$ GDP (in 2005 PPP \$). For India, China, Brazil, UK, France, US, and Germany, the measures were $211,317,136,116,143,183$, and 131, respectively. Except for the US, OECD countries have high energy efficiencies. Brazil is also in the OECD neighborhood. With 317 kgoe China is the outlier, although in 1990, its efficiency measure was 690 kgoe. Pakistan can learn from China's and OECD experiences when it attempts to improve its energy efficiency to the level of Brazil or OECD countries. The US's relatively lower than OECD level efficiency is due primarily to two factors: One, about 50 percent of its electricity is generated by coal; two, its energy prices do not incorporate external costs. ${ }^{2}$ France, the UK, and Germany have high energy efficiencies due to a mix of energy-wide policies, particularly that of pricing energy to incorporate external costs and the use of nuclear energy for electricity production.

If energy efficiency and clean energy are not seen as an "either/or" proposition, incremental investments in clean energy will spur economywide investments to improve energy efficiency and promote energy conservation, as the higher per KWh costs of new technology will make investments in energy efficiency more attractive. More efficient use of energy should/will lower the cost of building the new infrastructure as less generation capacity will be needed. The interplay between clean energy and energy efficiency would then function as a "virtuous cycle."

The Chinese's successful effort to increase its energy efficiency from 690 kgoe per $\$ 1,000$ GDP to 317 kgoe in 15 years can have important lessons for Pakistan. Dr. Phillip Andrews-Speed ${ }^{3}$ of the University of Dundee has summarized the essence of the Chinese experience as follows:

\footnotetext{
${ }^{2}$ External cost is the unaccounted and/or uncompensated adverse impact of the activities of one group on another group. The adverse impact can be on health, crops, material, or recreation.

${ }^{3}$ Andrew-Speed, P., China’s Drive for Energy Efficiency, April 2009.
} 
Fuel shortages and blackouts had become widespread by end of 2002, and were a serious threat to the economy. The Development Research Center of the State Council published the most authoritative report, identifying the following main priorities for China's future energy policy:

- $\quad$ Placing greater emphasis on energy conservation and energy efficiency, especially in industry

- Maintaining domestic primary energy resources as the main source of energy supply, but improving the management of these resources.

- Enhancing the role of the market within the domestic energy sector

- Increasing the use of hydro-electricity, renewables, nuclear energy and natural gas, in order that reliance on coal may be reduced.

- Developing alternative transport fuels.

- $\quad$ Constructing emergency oil storage.

The above recommendations were implemented through quantitative goals. The energy efficiency-cum-conservation plan sought to reduce energy intensity by 20 percent between 2005 and 2010-an annual average of 3.6\% per year-and to continue this decline at the same rate till 2020.

The Chinese strategy reinforces key lessons from the experience of OECD countries, i.e., there is no silver bullet policy for achieving energy efficiency. The European lessons are that a comprehensive policy package is necessary to accomplish significant improvements. The package could include a range of instruments from each of the following policy types:

- Applying a market-wide price signal for effective and cost-efficient emission reductions $\left(\mathrm{SO}_{2}, \mathrm{NO}_{\mathrm{x}}, \mathrm{CO}\right.$, and $\left.\mathrm{CO}_{2}, \mathrm{CH}_{4}\right)$ from the economy-wide use of energy.

- Adopting specific regulations, including codes, performance standards and mandatory actions that increase energy efficiency and/or energy conservation. 
- Targeting subsidies such as capital and fiscal incentives, technology funds, and funding programs for skill development. Subsidies should be nontechnology-specific so as not to act as a barrier to innovation and should account/adjust for issues related to free ridership. Evaluation and adjustment is necessary to adjust such targeted programs.

- Energy efficiency targets should be set and monitored.

- Governance capabilities should be commensurate to the task.

These lessons can be used by Pakistan, if it so decides. The only difference will be that China uses coal extensively while Pakistan may be considering it. Pakistan should utilize domestic energy resources, but it should be clean coal and environmentally friendly hydel. Pakistan must also integrate external cost in its policy choices.

External cost is considered next in the discussion on energyenvironment links and the virtue of linking energy efficiency with environmentally friendly energy.

The environment is the receptacle of energy inefficiency. The European Commission through its Extern-E project and the USA through its National Academy of Science Project have both quantified the links between energy and environment. The common objective of both was to estimate the external cost of energy production/conservation/utilization.

An external cost arises when the social and economic activities of one group have an adverse impact on another, and the first group is neither held accountable nor compensates for being responsible for the adverse impact.

Table-2 defines a subset of the external costs that can arise from energy production/conversation/utilization. Seven major types of damages were considered by both the European and American studies: both studies also estimated (with large associated uncertainties) the damages caused by greenhouse gases (GHGs): carbon dioxide, methane, nitrogen oxides, nitrates, and sulfides. Some GHGs are also classic pollutants $\left(\mathrm{SO}_{2}, \mathrm{No}_{\mathbf{x}}, \mathrm{CO}\right.$, $\mathrm{N}, \mathrm{S}, \mathrm{PM}_{10}$ ) and directly or indirectly cause damage to health, crops, and materials. Methane is the main component of natural gas and is many times more potent than carbon dioxide. GHGs and classic pollutants are produced in different quantities by different fossil fuels (coal, oil, and gas) and also depend on technology used in the production and conversion processes. 
At Pakistan's current level of energy consumption, GHGs are not as important as classic pollutants, but in the medium term they will become important variables in decisions about energy production and use.

The European Commission estimates for the external cost of electricity generation are given in Table-3. The variability in the estimates reflects the effects of location, technology, and fuel quality.

The results suggest that wind technologies are the most environmentally friendly with respect to both GHGs and classic pollutants. However, wind technologies are location-dependent. Nuclear power also generates a low external cost even though the very low possibility of accidents with very high cost consequences and fuel cycle impacts are included. Nuclear power also produces a very low level of GHG emissions. Natural gas-fired technologies are quite clean with respect to classic pollutants, but their impact on climate change depends on the efficiency of the conversion technology. For example, the newer combined-cycle technologies produce low to average GHG impacts.

\section{Table-3: External Cost ${ }^{\text {a }}$ for Electricity Production in the European Union for Existing Technologies (US cents/KWh)}

\begin{tabular}{lccccccc}
\hline Fuel & Denmark & France & Germany & Norway & Spain & Sweden & UK \\
\hline Coal and Ignite & $5.4-9.5$ & $9.5-13.6$ & $4.1-8.2$ & & $6.8-10.9$ & $2.7-5.4$ & $5.4-9.5$ \\
Oil & - & $10.9-15$ & $6.8-10.4$ & - & - & - & $4.1-6.8$ \\
Natural Gas & $2.7-4.1$ & $2.7-5.4$ & $1.4-2.8$ & $1.4-2.8$ & $1.4-2.8$ & - & $1.4-2.8$ \\
Nuclear & - & 0.4 & 0.3 & - & - & - & 0.3 \\
Biomass & 1.4 & 1.4 & 1.4 & 0.2 & $4.1-6.8^{\mathrm{b}}$ & 0.4 & 1.4 \\
Hydro & - & 1.4 & - & 0.2 & 0.04 & 0.07 & - \\
Photovoltaic & - & - & 0.8 & - & - & - & - \\
Wind & 0.15 & - & 0.3 & 0.3 & 0.3 & - & 0.2 \\
\hline & $\begin{array}{l}\text { Sum total of quantifiable externalities: public health, occupational health, } \\
\text { material damage, global warming. }\end{array}$ \\
b) & $\begin{array}{l}\text { Biomass co-fired with ignite. } \\
\text { Euro cents converted to US cents by multiplying by 1.36. }\end{array}$ \\
Coal technologies, no matter how one looks at it, carry the GHG \\
burden of their high carbon dioxide emissions. Old coal-fired plants are also \\
very high emitters of classic pollutants. This combination makes coal \\
technologies the worst available for the production of electricity.
\end{tabular}


US estimates of external costs focus on monetizing the lifecycle damage of major air pollutants-sulfur dioxide, nitrogen oxides, ozone, and particulate matter-on human health, crops, forests, buildings, and recreation. Separately, the Research Group also derived a range of values for damages by GHGs. As with the European study, the uncertainty associated with the estimates of impact on climate lifecycle change are much larger. Coal accounts for about half the electricity produced in the US. The total non-climate damage by coal-generated electricity was estimated at US\$62 billion in 2005 . These damages (external costs) translate to about US 3.2 cents/KWh produced - an estimate at the lower end of the European Commission estimate spectrum which included climate-specific damages. The climate-specific damage from coal-generated electricity in the US was estimated to be in the range of 0.1 US cents to 10 US cents per KWh. With this addition, the US estimates fully overlap with the European estimates for coal.

For gas-powered generation of electricity the estimated lifecycle external cost was much lower: 0.16 cents per KWh produced. Estimated climate damages from gas accounted for 0.05 to 5 cents per $\mathrm{KWh}$ produced i.e., one half that from coal. The lifecycle damages of wind-produced electricity are small in comparison with coal or natural gas. So are the damages from the 104 operating nuclear reactors accounting for 20 percent of the electricity produced. But the lifecycle of nuclear power poses special risks: uranium mining and the storage of radioactive waste. These risks remain unevaluated at the global level, particularly if, to minimize climate change impacts, nuclear power acquires a much greater share (in the US and in the world) in the production of electricity. Lifecycle emissions of GHGs from nuclear-generated electricity are negligible in comparison with that produced from fossil fuels.

Besides generating electricity, fuels are also used to generate heat and to energize mobile vehicles (cars, buses, rail). Heating is mostly fueled by natural gas or electricity (produced by a variety of fuels). The median damages in residential and commercial buildings were about 11 cents per thousand cubic feet.

Transportation-related external costs (mainly from oil) were estimated to be US\$ 56 billion in 2005 . These are roughly similar to the external costs from coal-powered electricity. Damages per vehicle-miles travelled ranged from US cents 1.2 to 1.7 . Non-climate damages from ethanol were similar to those from gasoline because of the energy needed to produce the corn and convert it to ethanol. However, ethanol made from second-generation herbaceous plants (switch grass, trees) has very low 
external costs. Second-generation bio-fuels are currently not commercially available, but hold great promise.

For Pakistan, we could not find any estimates of external cost from energy production or use. However, we have small sample (2007) estimates for the level of classic pollutants in some spots in a few cities: Gujranwala, Islamabad, Faisalabad, Quetta, Lahore, and Karachi. These estimates are from the Pakistan Environmental Protection Agency ${ }^{4}$ with the help of the Japan International Corporation Agency (JICA). The estimates focus on particulates $\left(\mathrm{PM}_{10}\right.$, TSP) and nitrogen oxides $\left(\mathrm{NO}_{\mathrm{x}}\right)$. The concentration of particulates is about 30 times higher than World Health Organization (WHO) standards for the 24 hour average for $\mathrm{PM}_{10}$ and TSP in Gujranwala; for nitrogen oxides, the highest concentration was in Karachi: about 400 $\mathrm{ug} / \mathrm{m}^{3}$. This is more than ten times the WHO standard of $30 \mathrm{ug} / \mathrm{m}^{3}$. The point is that Pakistan has neither an adequate representative database for the external cost of classic pollutants nor any link with fuel choices and related energy supply policy. This is a key message if Pakistan is to develop a socially and environmentally responsible policy for the energy sector.

For a rational energy policy in the context of declining fossil fuels and huge external costs, Pakistan will have to acquire an implementation capability that combines policy shifts with significantly improved implementation capabilities. Given the pollution numbers, the external cost in Pakistan will be far higher than the European and US estimates. If so, future energy policy will require a major policy shift to integrate external cost in choices about energy supply with appropriate subsidies and taxation policies. It will also require the ability to implement large infrastructure projects, if the policy shifts so dictates, i.e., more to nuclear, gas (pipelines), renewable $(\mathrm{R} \& \mathrm{D})$, clean coal, and bio-fuels. These shifts will require capacity building, enhanced R\&D and policy coordination. Since environmental issues are a relatively new concern for most developing (or even developed) country governments, there is need to mainstream these sectoral/policy links. In order to get a sense of the magnitude of the efforts needed by Pakistan to make the required shifts in policy and create enabling capacity, it is worthwhile to briefly review the implementation performance of Pakistan during the past several decades (and several governments). This brief review is confined to the implementation experience in (i) large dams; (ii) ongoing discussion with Iran, Turkmenistan, and Qatar for natural gas pipelines; and (iii) the power sector.

\footnotetext{
${ }^{4}$ Lodhi (2007).
} 


\section{Experience with Implementation Performance of Large Energy Projects}

\section{Large Dams}

The Indus Basin works were implemented with acceptable delays for large projects. The works included Mangla and Tarbela dams, link canals, and the public sector Salinity Control and Reclamation Program (SCARP). The involvement of international financial and technical assistance working with a strong Water and Power Development Authority (WAPDA) (with the late Syed Salar Kirmani as chief engineer) was primarily responsible for this satisfactory implementation performance. Kalabagh dam, on the other hand, has yet to see completion even though it pre-dates (1950) Tarbela as the first proposed large dam on the Indus. President Ayub Khan, technically supported by Mr Kirmani, preferred Tarbela (proximity to Ayub Khan's village was given as one possible reason) over Kalabagh. Kalabagh dam was again recommended by the World Bank/WAPDA Revised Action Plan (in 1979) and a feasibility study financed by the World Bank was completed in the early 1980s. The proposal to build Kalabagh as the second dam on the Indus fell by the wayside due to political conflicts. President Musharraf made a fresh effort in the early $21^{\text {st }}$ century, but did not succeed.

A substitute, Diamer Bhasha Dam, was proposed in the 1990s and is politically more acceptable. This dam has the additional advantage of stopping the sedimentation of Tarbela, thus extending its life by many decades, possibly a century. However, the project with a 4,000 MW

potential also seems to be withering on the vine in spite of the financial and technical support of two multilateral banks. Meanwhile, the energy deficit, with long hours of load-shedding continues, being addressed by inadequate band-aid solutions like thermal turbines on barrages or rented thermal power plants. The economic cost of the load shedding is quite high.

\section{International Natural Gas Pipelines}

There are three pipelines under consideration:

1. Iran-Pakistan-India (IPI) pipeline,

2. Turkmenistan-Afghanistan-Pakistan (TAP) pipeline, and

3. Qatar-Pakistan (QP) pipeline (see map overleaf). 


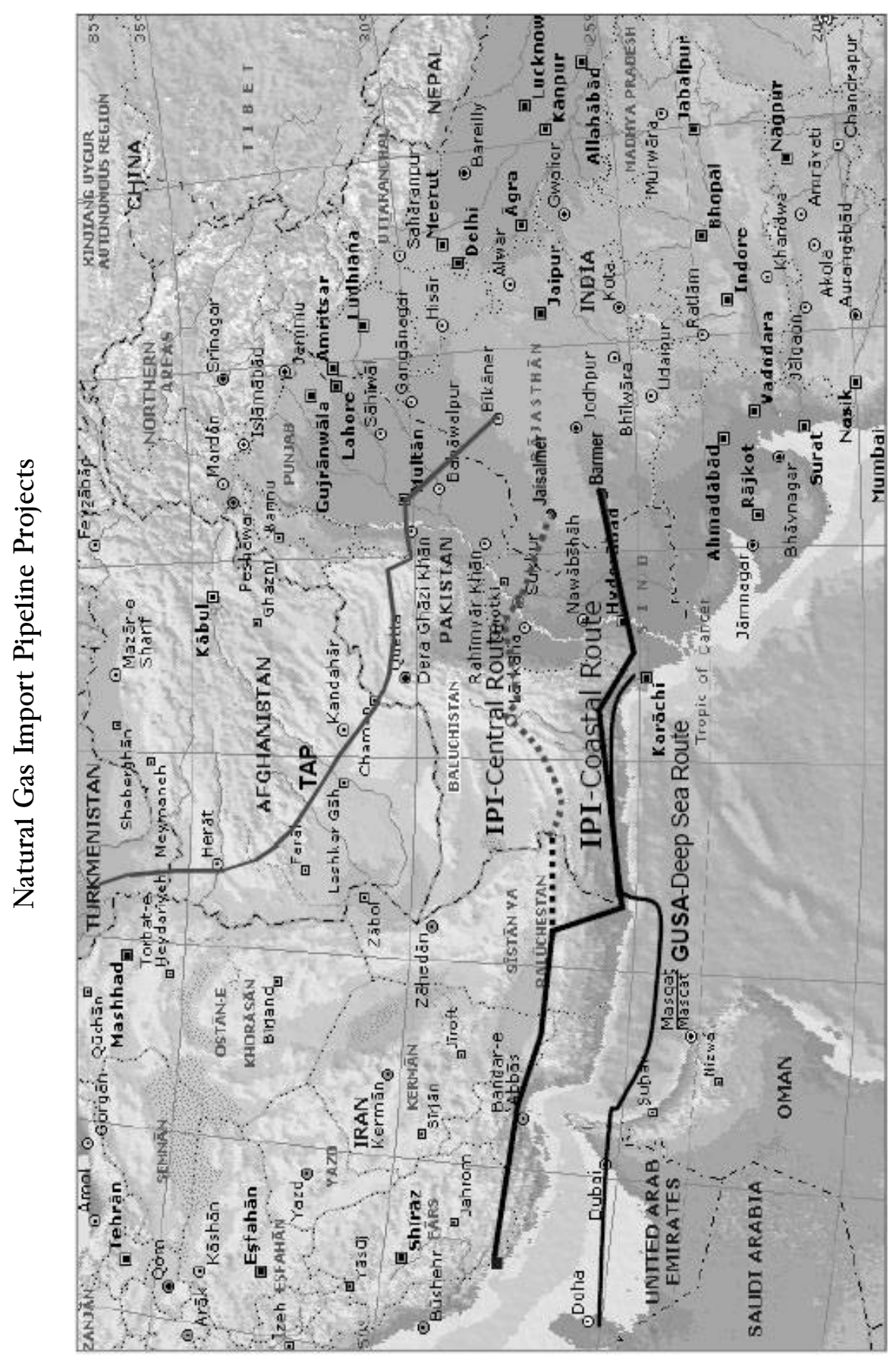


The IPI was conceptualized in 1989 and a memorandum of understanding (MOU) signed in 1993 to construct this 2,670 km pipeline with a 3,620 mmcfd gas transmission capacity. Had this pipeline been completed during the 1990s, Pakistan would have solved its energy problems for at least half a century. However, discussion continues in 2010 when the political situation in the region (the US, Iran, Afghanistan, Balochistan) makes it highly risky to construct this pipeline. Further, the US's foreign policy supports the TAP route or liquefied natural gas (LNG) from Qatar.

The MOU for the TAP pipeline was signed in 1994, one year after the IPI MOU. This is a $1,270 \mathrm{~km}$ pipeline through war-torn Afghanistan. While in the 1990s, it might have been a feasible investment, it is now a highly risky investment given the current law and order situation in Afghanistan. The QP pipeline is technologically complex because it will be undersea for part of the route. Discussions on this also began in the 1990s. Recently, LNG imports from Qatar are under discussion once again, possibly because the US actively supports this as a partial solution to the energy problem of Pakistan and/or as a policy that further isolates Iran.

\section{Pakistan's Power Sector}

Pakistan's power sector has been in a constant state of flux for the last 20 years. In the 1990s, Pakistan led developing countries in the utilization of independent power producers (IPPs) to address domestic electricity deficits. In the mid-1990s, the deficit in Pakistan was about 2,000 MW. The IPPs' response was overwhelming and the deficit was allegedly converted into a surplus by the late 1990s. This response from the IPPs was due mainly to the US cents $6.5 / \mathrm{KWh}$ purchase price offered with a guaranteed purchase of power by WAPDA. The 6.5 cents/KWh purchase price was twice what Bangladesh offered, occurring through a contractual process which minimized the price of energy. Pakistan, on the other hand, offered a high minimum price to facilitate, it is alleged, hefty kickbacks. The presence of corruption in public projects has plagued the power sector and the costs are being borne by ordinary people. As a result, the power deficit continues with a low likelihood of solutions in the medium term. Thermal solutions through rented turbines can, at best, be no more than band aid solutions.

Restructuring WAPDA and privatizing the KESC also does not seem to have any traction. Karachi and the country continues to face load-shedding on a significant scale and WAPDA's institutional restructuring ${ }^{5}$ of the power

\footnotetext{
${ }^{5}$ Hagler Bailly Pakistan (2008) and Ahmed (2007).
} 
sector with four thermal generation companies (GENCOs), one central national transmission and dispatch company (NTDC) and nine distribution companies (DISCOs) has not changed the internal incentive structure which is what the separation of generation and distribution into competing units is supposed to do. These GENCOs are managed by the Pakistan Electric Power Company (PEPCO) under the aegis of WAPDA's financial controls. The ultimate plan remains to be implemented when GENCOs and DISCOs can provide competition in areas of common presence.

WAPDA plus the KESC have a generation expansion plan to add $50,000 \mathrm{MW}$ by 2025 , of which about 64 percent of the additional capacity will be principally oil-powered, unless at least one gas pipeline is completed or LNG imports are feasible with adequate cold storage and gasification infrastructure available at the importing ports. In case it is oil-powered, the import cost will be large and so will be the $\mathrm{CO}_{2}$, sulfur, and nitrous oxide contributions to the already polluted environment. The plan also boldly projects that nuclear powered electricity will be $8,800 \mathrm{MW}$ (the current capacity is $462 \mathrm{MW}$ ).

The lessons from the brief survey of Pakistan's implementation performance are that governance (incentives, competence, and accountability) could be a major constraint to implementing the future programs and policies required to meet Pakistan's energy needs over the next two decades. Corruption and lack of accountability, it seems, will continue to dominate Pakistan's energy sector choices.

\section{Pakistan's Recent Energy Supply and Demand ${ }^{6}$}

The total energy supply in $2007 / 08$ was 62.92 MTOE. The dominant fuel was natural gas (48\%) with oil a close second $(31 \%)$. Total energy consumption in 2007/08 was 39.41 MTOE. Tables-4, 5, and 6 present the structure of supply and sectoral utilization. The industry, transport, and residential sectors utilize 92 percent, with industry being dominant with 43 percent utilization.

\footnotetext{
${ }^{6}$ Hagler Bailly Pakistan (2008) and Masud (2009).
} 
Table-4: Total Primary Energy Supply (2007/08)

\begin{tabular}{|c|c|c|}
\hline Fuel & MTOE & Percentage \\
\hline Natural Gas & 30.291 & 48 \\
\hline Oil & 19.206 & 31 \\
\hline Hydroelectricity & 6.852 & 11 \\
\hline Coal & 5.784 & 9 \\
\hline Nuclear Electricity & 0.735 & 1 \\
\hline Imported Electricity & 0.048 & - \\
\hline Total & 62.92 & 100 \\
\hline Indigenous & - & 66 \\
\hline Imports & - & 34 \\
\hline
\end{tabular}

Table-5: Total Energy Consumption (2007/08)

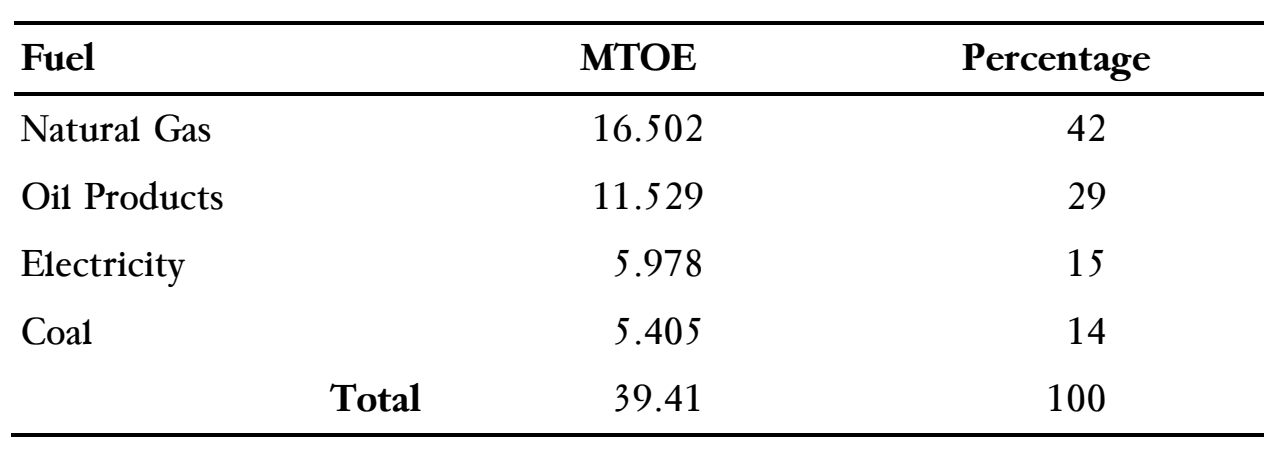

Table-6: Total Energy Sector Utilization (2007/08)

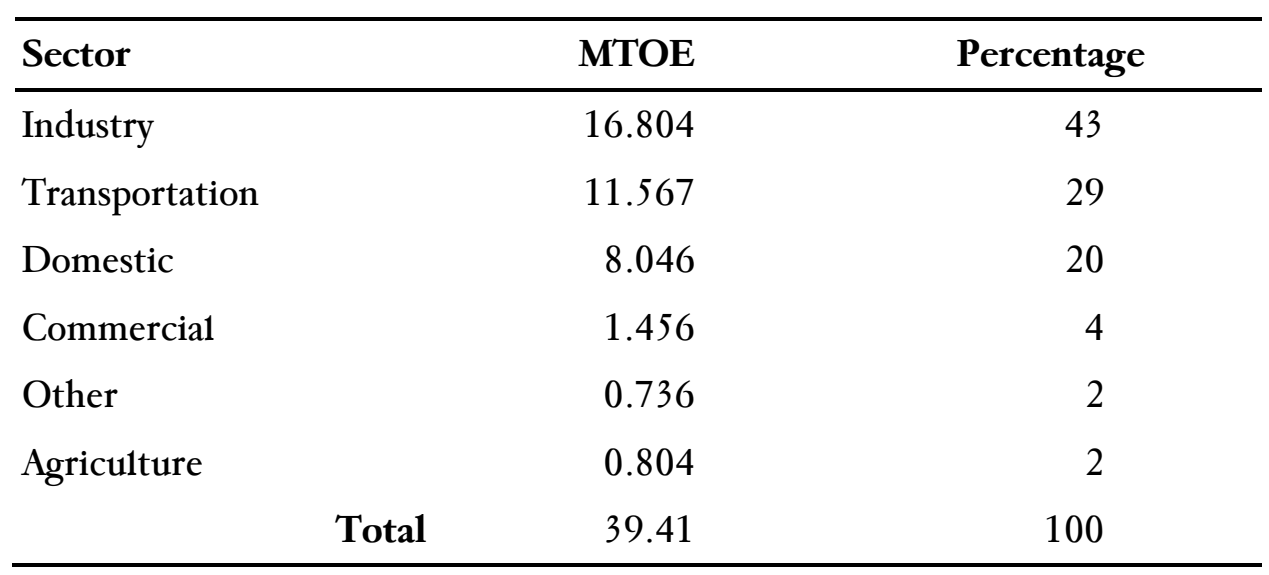


In 2010, the estimated energy deficit is expected to be 19 MTOE or about 26\% of 2010 energy requirement (Hagler Bailly Pakistan, 2008). Electricity use increased by 7 percent per annum during 2002-07 with generation growth lagging at 4.8 percent per annum. System-wide technical and distribution losses averaged $30 \%$. Serious power shortages began in 2007/08 and have worsened in 2010.

\section{Pakistan's Domestic Energy Resource Potential}

The energy resource potential of the country is presented in Table-7 and 8 (Ahmed, 2007). The reserve to production ratio is 14 and 21 for oil and gas, respectively. For measured coal, the reserve to production ratio is 678. Pakistan claims to have 185 billion tons of coal deposits in the Thar Desert. This coal is of relatively low quality with a heating value ${ }^{7}$ of 15 $\mathrm{MJ} / \mathrm{kg}$ (see below), a sulfur content of over 1 percent, ash over 6 percent, and moisture of about 50 percent. The overburden covering the coal deposit has a depth of 175-230 m requiring capital-intensive open-pit mining.

\begin{tabular}{lc}
\hline Coal & Heating Value MJ/kg \\
\hline Lignite & 15 \\
A Thar Kind & $15-19$ \\
B Higher & $19-27$ \\
Sub-Bituminous & $24-32$ \\
Bituminous & $32-33$ \\
Authracite & \\
\hline
\end{tabular}

Limited water availability in the region (and nationally) also presents a severe constraint to the utilization of these coal deposits. Pakistan has a theoretical hydel potential of $40,000 \mathrm{MW}$, of which 16 percent is currently utilized. But this potential is unlikely to be fully realized due to two major factors: One is environmental constraints; the second is the rapid melting of the Himalayan glaciers (International Panel for Climate Change 2007) with a predicted reduction of river water flows by 35 to 40 percent over the next 40 years. This would present serious trade-offs between power production and irrigation/urban water demands on the use of reservoir water.

\footnotetext{
${ }^{7}$ Heating values of higher-quality coals range up to $33 \mathrm{MJ} / \mathrm{kg}$.
} 
Table-7: Indigenous Energy Resource

\begin{tabular}{lll}
\hline Resource & Estimate Potential & Energy Content \\
\hline Oil & 336 million barrels & $45 \mathrm{MTOE}$ \\
Gas & $29 \mathrm{tcf}$ a $900 \mathrm{Btu} / \mathrm{scf}$ & $628 \mathrm{MTOE}$ \\
Coal, Measured & 3,303 million tons & $1477 \mathrm{MTOE}$ \\
Coal, Inferred & 56,382 million tons & $25,220 \mathrm{MTOE}$ \\
Coal, Hypothetical & 113,798 million tons & $50,903 \mathrm{MTOE}$ \\
Installed Hydel & - & $6595 \mathrm{MW}$ \\
Potential Hydel & - & $40,000 \mathrm{MW}$ \\
\hline
\end{tabular}

Source: Ahmed (2007).

Table-8: Annual Production of Energy Source 2006/07

\begin{tabular}{lcl}
\hline Fuel & Annual Production & $\begin{array}{c}\text { Reserve to Production } \\
\text { Ratio }\end{array}$ \\
\hline Oil & 24 million barrels & 14 \\
Gas & $1.4 \mathrm{Tcf}$ a $900 \mathrm{Btu} / \mathrm{scf}$ & 21 \\
Coal (Measured) & 4.87 million tons & 678 \\
Hydel Potential Realized & - & 16 percent \\
\hline
\end{tabular}

Source: Abmed (2007).

As noted earlier, so far natural gas is Pakistan's dominant fuel. Pakistan has historically been self-sufficient in gas. Oil has been imported and has been a significant consumer of foreign exchange. The primary energy supply in Pakistan has been increasing at 6 percent per annum during 2002-2007, electricity consumption at about 7 percent per annum, natural gas at 10.4 percent per annum, LPG at 17.6 percent per annum, and coal (half of which is imported) at 22.8 percent per annum.

\section{Projected Supply and Demand (2010-2030) ${ }^{8}$}

To satisfy these growth rates in energy demand will require imports of natural gas (via pipeline or LNG) and socially responsible (i.e., incorporating external costs in policy choices) utilization of domestic resources: coal, hydropower, biomass, and wind. If we factor in global warming, the aggressive

\footnotetext{
${ }^{8}$ Hagler Bailly Pakistan (2008).
} 
development of nuclear power may also become necessary. The Planning Commission's Medium Term Development Framework 2005-10 has projected total energy requirements at a GDP growth rate of 6.5 percent per annum as 198 MTOE in 2025. This is a fourfold increase compared to the total energy requirement in 2005. The projected deficit in 2025 will be 122 MTOE or about 62 percent of the energy requirement. A subsequent forecast by Hagler Bailley Pakistan (2008) projects the total energy requirement with a lower 5.5 percent per annum GDP growth rate as $176 \mathrm{MTOE}$. The energy deficit as a percentage of energy requirement is however 71 percent due to the slower growth of indigenous energy. Table-9 summarizes the composition of Hagler Bailley's forecast and presents the composition of fuel imports. The high proportion of imports, particularly polluting oil, is problematic. The financing bill for this scenario is projected to be US\$25 billion in 2015 and $\$ 94$ billion in 2030. Of course, such long-term financial projections are not reliable. Several questions are pertinent and may provide directional guidance.

Table-9: Projected Energy Requirement and Energy Deficit (2010- 2030)

\begin{tabular}{lrrrrr}
\hline Energy Source (MTOE) & $\mathbf{2 0 1 0}$ & $\mathbf{2 0 1 5}$ & $\mathbf{2 0 2 0}$ & $\mathbf{2 0 2 5}$ & $\mathbf{2 0 3 0}$ \\
\hline Oil & 4 & 3 & 1 & 1 & 1 \\
Gas & 40 & 36 & 25 & 19 & 20 \\
LPG & 1 & 1 & 1 & 1 & 1 \\
Coal & 2 & 3 & 4 & 6 & 8 \\
Hydel & 7 & 8 & 15 & 17 & 24 \\
Renewable and Nuclear & 1 & 1 & 5 & 8 & 14 \\
Total Indigenous Supply & 55 & 52 & 51 & 52 & 68 \\
Total Energy Requirements & 73 & 96 & 131 & 176 & 238 \\
Energy Deficit & 18 & 44 & 80 & 124 & 170 \\
& Imports for the Deficit & & & \\
Oil & 14 & 29 & 46 & 64 & 85 \\
LNG or Gas & - & 4 & 18 & 34 & 48 \\
LPG & - & 1 & 2 & 3 & 4 \\
Coal & 4 & 10 & 14 & 23 & 33 \\
\hline
\end{tabular}

1. What criteria should Pakistan use to choose the composition of energy supply? The composition relates to domestic alternatives: hydropower, coal, biomass, wind, and solar. 
2. Can demand management and energy efficiency significantly reduce total energy requirements?

3. Why is oil so dominant? Why not substitute natural gas for oil?

4. Why should LNG imports not be Pakistan's priority over the next five years since in this timeframe a natural gas pipeline from central Asia or Iran is politically and economically infeasible?

5. Why not develop clean energy from domestic coal? Why will 14 MTOE be contributed by imported coal in 2020?

6. Why not significantly substitute renewable for imported energy? What must Pakistan do to accelerate renewable energy developments?

7. Why not consider the aggressive development of nuclear energy?

\section{Total Cost as a Criterion for Energy Supply Composition}

The above questions provide context and some direction. A comparative evaluation of the external cost of fossil, nuclear, and renewable fuel cycles reveals a wide range (Table-3). As discussed earlier, wind technologies are the most environmental friendly. Nuclear power also generates a very low external cost. Biomass impacts can range from low to high on pollution but have low GHG emissions. Photovoltaic energy is very clean/green, but so far not commercially available for MW level solar units. However, it is the future sustainable technology because R\&D will (surely) bring the cost to fossi1/nuclear competitive levels. Gas-fired technologies are also very clean with respect to classic pollutants, but their impact in terms of GHG emissions depends on the efficiency of the gas cleaning technology.

Coal technologies are the most polluting (GHGs and classic pollutants) because of their carbon dioxide content. Old and current coal-fired plants are also significantly more polluting in terms of $\mathrm{SO}_{2}, \mathrm{NO}_{\mathrm{x}}$ and $\mathrm{CO}$ ). For the US, the environmental protection agency (EPA) identifies the following (Table-10) average emission levels in the production of $1 \mathrm{MWh}$ of electricity. Due to lax enforcement as well as inadequate environmental regulation, in Pakistan emission levels are much higher. However, Pakistan does not have estimates of external cost for local conditions and technologies in use for competitive fuels. What we do know is that the emission of $\mathrm{SO}_{2}, \mathrm{NO}_{\mathrm{x}}, \mathrm{CO}$, and $\mathrm{PM}_{10}$ is significantly higher than that of these pollutants in Europe or the US. So, the external cost in Pakistan will be higher. 
Table-10: Pounds of Emissions per MWh

\begin{tabular}{lccc}
\hline & Carbon Dioxide & Sulfur Dioxide & Nitrogen Oxide \\
\hline Coal & 2,249 & 13 & 6 \\
Oil & 1,672 & 12 & 4 \\
Natural Gas & 1,135 & 0.1 & 1.7 \\
Nuclear & 0 & 0 & 0 \\
\hline
\end{tabular}

Source: http://www.epa.gov/cleanenergy/

To get a lower limit estimate, we have therefore added the median of European external costs to Pakistan's internal costs of electricity generation. This "total cost" is presented in Table-11. The addition of external costs makes hydel and nuclear power more cost effective than natural gas and coal. So, if total cost were to be the principal choice criterion, Pakistan could rationally choose to focus on its hydel potential while adding significantly to its nuclear power capacity.

Table-11: Total Cost of Electricity Generation

\begin{tabular}{lcccccc}
\hline Fuel & \multicolumn{3}{c}{$\begin{array}{c}\text { Internal Cost of Electricity } \\
\text { Generation* }\end{array}$} & $\begin{array}{c}\text { Median } \\
\text { External** }\end{array}$ & $\begin{array}{c}\text { Total } \\
\text { Cost }\end{array}$ \\
\hline & Capital O\&M & Fuel & Total & & \\
\hline Gas & 1.7 & 0.9 & 2.7 & 5.3 & 2.8 & 8.1 \\
LNG & 1.7 & 0.9 & 4.1 & 6.7 & 2.8 & 9.5 \\
HSFO $^{* * * *}$ & 1.6 & 1.0 & 6.5 & 9.1 & 10.4 & 19.5 \\
Coal-Imported $^{* * * * *}$ & 2.3 & 1.0 & 2.4 & 5.7 & 6.8 & 12.5 \\
Coal-Thar & 2.5 & 1.0 & 2.5 & 6.0 & 6.8 & 12.8 \\
Hydel & 5.0 & 0.1 & & 5.1 & 0.2 & 5.3 \\
Nuclear & 4.6 & & 1.1 & 5.7 & 0.3 & 6.0 \\
\hline
\end{tabular}

* Ahmed (2007):Exhibit-9, pg. 27

** European Commission (2003) Table-3

*** HSFO: High Sulfur Fuel Oil. HSFO price corresponds to US \$ 60/barrel of Crude

**** Delivery price of imported coal at US \$ $75 /$ ton

With a potential 40,000 MW of hydropower of which only 16 percent has been realized, there is considerable room to develop. However, it has proven difficult for Pakistan to develop its hydel resources. As discussed earlier, 
Kalabagh Dam has been under discussion since 1950 and Diamer Bhasha Dam for at least a decade. Will the future be different? On nuclear power, the current capacity is $462 \mathrm{MW}$ and a third $325 \mathrm{MW}$ plant expected by 2011. The Pakistan Atomic Energy Commission has been authorized (an unfunded mandate it seems) to develop $8,800 \mathrm{MW}$ of capacity by 2030 . Will that be feasible in the current political situation in the region even though the regional and global status of nuclear power production" should justify an ambitious nuclear energy development plan for Pakistan? Since natural gas is cleanest among the fossil fuels, its import via pipelines or LNG should be a high medium-term priority. Finally, clean coal, second-generation bio-fuels, solar, wind, and mini-hydropower are energy sources with a sustainable unrealized potential. Their significant development will however require technological innovation for which Pakistan needs a strong research and development (R\&D) program and the institutional integration of private sector, academia and government. Pakistan currently invests about $0.25 \%$ of its GDP in R\&D. India invests $0.85 \%$, China $1.44 \%$, Bangladesh $0.62 \%$, and Israel $4.4 \%$

Globally, France has $76 \%$ of its electricity produced by nuclear energy, producing $418 \mathrm{TWh}$ in 2008. USA has $20 \%$ of its electricity produced by nuclear energy and produced 809 TWh in 2008

\section{Cleaner, Sustainable Energy Sources}

Transitioning to sustainable energy sources poses significant challenges for all countries. Pakistan is no exception. Over the next decade, it should be possible to accomplish a low carbon path to growth through new energy technologies, greater energy efficiency and sustainable renewable energy sources. Since most of today's fossil fuel-dependent capital stock will be gradually replaced, it will take a decade or more to accomplish significant substitution and demand reduction. A few promising, high-value technologies approaching commercialization are discussed below.

Coal to Liquid and Coal to Gas. The conversion of coal to oil products through gasification and synthesis has been commercially feasible for many decades, but global production is limited. This possibly is due to the absence of carbon pricing as well as the associated large energy and water requirements. This should begin to change after Copenhagen and the dwindling of non-coal fossil fuels. Coal to methane conversion is also a reliable technology awaiting appropriate policies on carbon pricing. Given Pakistan's

\footnotetext{
${ }^{9}$ Both India and China have 2 +percent of electricity generated by nuclear energy. India produced 13.2 Twh in 2008; China produced 65.3 Twh; Pakistan produced 1.7 Twh.
} 
large coal deposits this is a high-value technology for development, although the required R\&D capability has to be created.

- Carbon Capture and Storage. This is a technology which mitigates emissions of $\mathrm{CO}_{2}$ from power plants and other fossil fuel using facilities. So far, again due to the absence of carbon pricing, it has not been applied on a significant ${ }^{10}$ scale. Pakistan should consider experimentation with this technology as well-the world will be doing so within this decade.

- Second-Generation Bio-Fuels: First-generation bio-fuels (corn and sugarcane) competed with food crops. New bio-fuel technologieshydrolysis and gasification of lignocelluloses feedstock to produce ethanol-are expected to reach commercialization in five to ten years. The heat content ranges of second-generation bio-fuels stocks are given in Table- 12 .

\footnotetext{
${ }^{10}$ Four large scale carbon capture and storage projects are operating in the world each separating one mega ton of $\mathrm{CO}_{2}$ per year from produced natural gas. These are Steipner and Snohrit in Norway, Weybarn in Canada, and Salah in Algeria.
} 
Table-12: Heat Content Ranges of Various Biomass fuels (Dry Weight Basis)

\begin{tabular}{|c|c|c|c|}
\hline \multirow{3}{*}{ Fuel Type and Source } & \multicolumn{2}{|c|}{ Heating Value } & \multirow[b]{2}{*}{ Cellulose Content' } \\
\hline & Higher & Lower & \\
\hline & \multicolumn{2}{|c|}{$\mathrm{MJ} / \mathrm{Kg}$} & Percent \\
\hline \multicolumn{4}{|l|}{ I - Agriculture Residues } \\
\hline - Corn Stalks/Stover & $17.6-18.5$ & $16.8-18.1$ & 84 \\
\hline - Sugarcane biogases & $17.3-19.4$ & $17.7-17.9$ & 96 \\
\hline - Wheat Straw & $16.1-18.9$ & $15 .-17.7$ & - \\
\hline \multicolumn{4}{|l|}{ II - Herbaceous Crops } \\
\hline - Switch grass & $18.0-19.1$ & $16.8-18.6$ & 85 \\
\hline - Other grasses & $18.2-18.6$ & $16.9-17.3$ & - \\
\hline \multicolumn{4}{|l|}{ III - Woody Crops } \\
\hline - Black locust & $19.5-19.5$ & 18.5 & - \\
\hline - Eucalyptus & $19.0-19.6$ & 18.0 & - \\
\hline - Hybrid Poplar & $19.0-19.7$ & 17.7 & 97 \\
\hline \multicolumn{4}{|l|}{ IV - Forest Residues } \\
\hline - Hardwood & $18.6-20.7$ & - & 95 \\
\hline - Softwood & $18.6-21.1$ & $17.5-20.8$ & 89 \\
\hline \multicolumn{4}{|l|}{ V - Urban Residues } \\
\hline - Newspaper & $19.7-22.2$ & $18.4-20.07$ & - \\
\hline - Corrugated cartons & $17.3-18.5$ & 17.5 & - \\
\hline - Municipal solid waste & $13.1-19.9$ & $12.0-18.6$ & - \\
\hline
\end{tabular}

Sources: www1 .eere.energy.gov/biomass/feedstock www.ecn.n1/phyllis

Tillman, David, Wood as an Energy resource, Academic Press, NY, 1978

*: Includes Hemi cellulose \& Lignin

Since we have alternative uses for agriculture residues, their diversion for energy will have an opportunity cost which has to be studied. However, herbaceous crops, woody crops, forest residues, and urban residues are not extensively utilized for productive value and offer potentially large economic opportunities, associated employment and sustainable energy.

Globally, the share of renewables in primary energy supply, excluding traditional biomass, is projected to reach 10 percent by 2030 . This projection assumes that renewable technologies will mature and higher fossil fuel prices will make these technologies competitive. Wind power is projected to grow the fastest. Denmark currently is the world leader with 15 percent of electricity generated from wind. USA is second with 8 percent. Pakistan has a potential of about 50,000 MW which, at this time, has hardly been tapped. 


\section{Recommendations}

Energy sector planning is by definition a long-term process. However, all such planning requires a phased approach requiring:

A. URGENT actions in the short term (1 to 2 years)

B. IMPORTANT actions in the medium term ( 3 to 7 years)

C. LONG-TERM actions over 8 to 20 years

A) Urgent Actions (2010-2012)

i. The most critical action is to utilize the existing unutilized electricity generation capacity. This would require temporarily addressing the circular debt problem; and soon after, solving the structural problem underlying this devastating recurrent adverse event.

ii. Expedite the process for LNG imports from Qatar.

iii. Initiate investments in deep freezing and gasification infrastructure needed for LNG imports.

iv. Initiate a system-wide study to estimate the external cost of the current utilization of energy in electricity generation, transportation, and industry. The Analytical System-Extern-E- developed by the European Commission may be used with appropriate modifications for application in Pakistan. Since Extern-E is a European Commission project, the Commission's involvement as a technical partner may be efficient. It should be a joint Pakistan-Commission study to create domestic capacity to carry on subsequent work and the required monitoring program. For classic pollutants and GHGs, Pakistan's EPA should consider heading this project along with one or more domestic academic institutions.

B) Important Actions (2013-2020)

i. Urgent actions are also important actions. Ensuring the finalization of all of the above is the first important action.

ii. Based on the result of A (iv) above, develop a comprehensive policy package including instruments from the following policy types: 
Market-wide price signals to promote conservation and energy efficiency.

Develop specific regulation including performance standards and mandatory actions by industry and power producers.

Design targeted subsidies such as capital and fiscal incentives, technology funds and programs for skill development. To promote innovation the technology funds should not be technology-specific.

iii. Initiate a program for the development of second-generation biofuels along with incentives to promote the substitution of bio-fuels for oil. Strengthen the Alternative Energy Development Board (AEDB) to lead this program in collaboration with industry and academia.

iv. Initiate projects for clean coal technology for power production.

V. All of these will require strong R\&D efforts. Pakistan should increase its R\&D budget from 0.25 percent of GDP to at least 1.0 percent by 2020 .

C) Long-Term Actions (2013-2030)

i. Finalize the IPI gas pipeline to diversify gas supplies and to impact positively the geo-political environment between India and Pakistan. The TAP pipeline is subject to much greater risk. The QP pipeline (with part of it under the sea) is costly and technologically risky.

ii. Initiate activities in hydropower, clean coal, nuclear power, and renewables to ensure that domestic primary energy resources are the main source of energy. Diamer-Bhasha should be part of the highest priority list with public-private partnership as the financing and management instrument.

iii. Nuclear energy for electricity is an environmentally friendly source and the 8,000 to $10,000 \mathrm{MW}$ target by 2030 should be funded along with a complementary educational and skill development program.

iv. Create capacity to enhance the role of the market within the domestic energy sector. Fully implementing the goals of reform in the electricity sector should be a high-priority objective, which means competition with effective regulation. 


\section{References}

Ahmed, M. (2007). Meeting Pakistan's Energy Needs, in Hathaway, Muchhala, R.M., B. Kugelman, M. (Eds.) Fuelling the Future: Meeting Pakistan's Energy need in the $21^{s t}$ Century, Woodrow Wilson International Center for Scholars, pp. 17-34.

Alternative Energy Development Board (Pakistan): Power Situation in Pakistan (2005).

Andrews Speed, P. (2009). China's Drive for Energy Efficiency. University of Dundee, Scotland.

Asia Pacific Environmental Strategies (APEIS) (2005). Research on Innovative and Strategic Policy Options (RISPO) Strategic Policy Options: Biomass; Energy Security; Hybrid Renewable Energy System.

Environmental Protection Agency (USA) (2008). Air Pollutions Manual.

European Commission (2003). External Costs - Research Results on SocioEnvironmental Damages due to Electricity and Transport.

Government of Pakistan (2010). Pakistan Economic Survey 2008-09.

Hagler Bailly Pakistan. (2008). Pakistan Energy Supply and Demand Forecast. Final Draft Report: HBP Ref: D8PE1AEO, DHA Cogan Limited, Karachi.

Lodhi, Z.H. (2007). Pakistan Environmental Protection Agency. Draft Article: Ambient Air Quality in Pakistan.

Masud, J. (2009). Clean Energy Development in Pakistan. Pakistan Power Point Presentation at ADB Climate Change and Energy Workshop, Bangkok, March $26-27,2009$.

MIT Interdisciplinary Study (2003). Update of the MIT 2003: Future of Nuclear Power.

National Academic of Sciences, USA (2005). The Hidden Costs of Energy Production - \$120 billion. McKone, Thomas and Colleagues.

Nawab, S.H (2007). Important Gas Pipeline Projects. Third Oil \& Gas Pakistan Conference. 
Ngo, Christian, Natoritz, and Joseph, B. (2009). Our Energy Future Resources, Alternatives and the Environment. John Wiley \& Sons, Inc.

Nuclear Share Figures (1998-2008). http://www.world-nuclear.org/ info/nshare.html

SCIENCE www.sciencemag.org Chow, J., Kop, R.J., Portney, P.R. (2003). Energy Resources and Global Development, 302.

Shazad, M.A. (Chairman), Pakistan Science Foundation: Science and Technology Funding System in Pakistan: www.nsfc.gov.cn/nsfc/ cen/1t1/22.htm

Stern, N. (2006). The Economic of Climate Change. The Stern Review Cabinet Office, HM Treasury Cambridge University Green.

The Numbers (2008). Carbon Emissions from Electricity Generation.

The World Bank (2003). World Development Report.

The World Bank (2009). Environment: From World Development Indicators (2009).

UNEP, NASA, World Bank (1998). Protecting our Planet; Securing Out Future.

www.world-nuclear.org/info/inf02.htm1 The Economics of Nuclear Power (Jan 2009)

www.world-nuclear.org/info/inf68.htm1 Energy subsidies and External Cost (Mr 2009). 
